\title{
EFEK EKSTRAK SAMBILOTO (ANDROGRAPHIS PANICULATA NEES) PADA EKSPRESI TELOMERASE DARI KANKER PAYUDARA TIKUS YANG DIINDUKSI DENGAN DMBA
}

\author{
Yurika Sastyarina $^{1)}$, Junaidi Khotib ${ }^{2)}$, Sukardiman ${ }^{3)}$ \\ Kelompok Bidang Ilmu Farmakologi-Farmasi Klinik, Fakultas Farmasi, \\ Universitas Mulawarman, Samarinda \\ e-mail:ureeqa@gmail.com ${ }^{1)}$ \\ Departemen Farmasi Klinik, Fakultas Farmasi, Universitas Airlangga, Surabaya ${ }^{2)}$ \\ Departemen Farmakognosi dan Fitokimia, Fakultas Farmasi, Universitas Airlangga, \\ Surabaya ${ }^{3)}$
}

\begin{abstract}
It has been well documented that chemical carcinogen, 7.12 dimethylbenz(a)anthracene (DMBA), plays a role in the incidence and growth of mammary cancer. Present study was designed to investigate the influence of Andrographis paniculata extract on telomerase activities on DMBA induced breast cancer in the female rat Sprague Dawley strain. DMBAinduced mammary cancer is a useful model to investigate the changes of epithelial cells that occur during mammary cancer progression. Mammary cancer model was induced 10 times twice a week by oral DMBA $20 \mathrm{mg} / \mathrm{kg}$ body weight. Mammary cancer occurred in $75 \%$ animals nine weeks after oral administration of DMBA, it was represented with nodule on the mammary gland and the increasing of mammary gland volume compare with normal control $F_{(1.8)}=731.711 ; p<0.001$. This study was also designed to investigate the effect of Andrographis paniculata extract mammary carcinoma induced by DMBA. Administration of three different dose of Andrographis paniculata (100 mg/kg, $300 \mathrm{mg} / \mathrm{kg}$ and $1000 \mathrm{mg} / \mathrm{kg}$ ) had statistically different with mammary gland volume of DMBA treated rat $F_{(4.17)}=92.777$; $p<0.05$. So, Andrographis paniculata has significant effect on the treatment of DMBA-induced mammary carcinoma. The Epithelial cells were harvested on day 90 and stained with routine histology staining, hematoxylineosin, for morphological qualitative analysis, immunohistochemical examination. The lesions observed from the removed samples ranged widely from benign to malignant. The results showed that DMBA induce cell proliferation, nuclear irregularities, and numerous mitoses and induced cell necrosis. The effect of Andrographis paniculata inhibits cell proliferation and induces apoptosis in cancer cells. On immunohistochemical examination, it shows that Andrographis paniculata can stimulate of telomerase enzyme.
\end{abstract}

Key word: Andrographis paniculata, DMBA, mammary cancer, cell proliferation

\begin{abstract}
ABSTRAK
Telah dilakukan penelitian efek ekstrak sambiloto (Andrographis paniculata Nees) pada ekspresi telomerase terhadap kanker payudara tikus betina (Sprague dawley) yang diinduksi dengan 7,12 dimethylbenz(a)anthracene (DMBA) menggunakan metode imunohistokimia. Diketahui model kanker payudara dengan induksi DMBA untuk menginvestigasi perubahan
\end{abstract}


Efek ekstrak sambiloto (Andrographis paniculata nees.) Pada ekspresi telomerase dari kanker payudara tikus yang diinduksi DMBA

dari sel epitel yang terjadi selama prorses karsinogenesis kanker payudara. Pemberian ekstrak sambiloto pada tikus yang mengalami kanker payudara menyebabkan penurunan volume tumor dan ditinjau dari aspek hispatologi dan imunohistokimia adanya ekstrak sambiloto menyebabkan penghambatan proliferasi sel, penurunan ekspresi telomerase dan meningkatkan apoptosis.

Kata Kunci : Andrographis paniculata,DMBA, kanker payudara, proliferasi sel

\section{PENDAHULUAN}

Kanker payudara adalah keganasan tersering dan penyebab kematian tertinggi pada wanita di dunia karena kanker. The US Centre for Disease Control and Prevention melaporkan bahwa di Amerika Serikat kanker payudara menempati peringkat ketujuh dari sepuluh besar penyebab kematian pada wanita (CDC, 2008). Sampai saat ini belum ada data statistik yang akurat di Indonesia, namun dari data berbagai rumah sakit yang ada menunjukkan kanker payudara menduduki urutan kedua dari seluruh keganasan pada wanita (Kusumawardojo, 2004).

Penatalaksanaan kanker payudara dilakukan dengan serangkaian pengobatan meliputi pembedahan untuk mengangkat jaringan kanker jika memungkinkan dan diikuti dengan terapi radiasi sinar- $X$ intensitas tinggi untuk membunuh sel kanker yang tidak terangkat pada saat pembedahan, kemoterapi dengan menggunakan obat-obatan dan reseptor hormonal. Pengobatan ini ditujukan pada upaya pengangkatan jaringan, memusnahkan sel kanker atau membatasi perkembangan penyakit serta menghilangkan gejala-gejalanya dan meminimalkan efek yang tidak diinginkan terhadap sel normal (King, 2000). Namun pada kenyataannya masih banyak obat kanker yang bekerja tidak selektif dimana selain membunuh sel kanker juga membunuh sel normal serta menimbulkan efek samping yang merugikan sehingga
Salah satu upaya yang dilakukan untuk mengatasi masalah tersebut adalah pencarian dan penemuan senyawa bioaktif dari tanaman obat Indonesia yang memiliki aktivitas antikanker, khususnya terhadap kanker payudara (Ganiswara, 1995; Meiyanto E., 2007; Sukardiman, 2007).

Sambiloto mengandung zat pahit andrografolida suatu senyawa diterpenoid yang diketahui memiliki efek antitumor. Peran antitumor andrografolida antara lain pada induksi apoptosis (kematian sel yang terprogram secara fisiologis) dan cell cycle arrest (Kumar et al., 2004). Adanya aktivasi p53 oleh Andrografolida melalui peningkatan fosforilasi p53 yang selanjutnya akan mempengaruhi proses siklus sel sehingga sel tidak akan mengalami pembelahan dan sel akan mati karena terjadi kondensasi kromosom yang menyebabkan terjadinya apoptosis (Andrew et al., 2002; Yalon et al., 2004; Sukardiman, 2007) sehingga berdasarkan dari penelitian tersebut maka diduga ekstrak sambiloto mempunyai aktivitas antimitosis dan pro-apoptosis pada sel tumor. Obat yang mempunyai efek antimitosis diduga juga mempunyai efek antitelomerase yang dapat menghambat pembelahan dan perkembangan sel yang sangat cepat seperti sel kanker dan berakibat terjadi kematian sel (apoptosis) (Anonim, 2004).

Dengan pendekatan patobiologi penelitian ini dilakukan untuk mengungkap adanya permasalahan terkait ekspresi dari 
Efek ekstrak sambiloto (Andrographis paniculata nees.) Pada ekspresi telomerase dari kanker payudara tikus yang diinduksi DMBA

telomerase tikus betina galur SD (SpragueDawley) yang diinduksi kanker payudara oleh DMBA menggunakan metode imunohistokimia yang diharapkan dapat menjelaskan mekanisme sambiloto (Andrographis paniculata Nees) dalam peranannya sebagai antikanker pada penurunan ekspresi telomerase.

\section{METODE DAN PENELITIAN}

\section{Bahan uji}

Bahan uji yang dipakai dalam penelitian ini adalah ekstrak sambiloto (Andrographis paniculata Nees) yang diperoleh dari IKOT Tradimun Gresik. Untuk pembuatan model kanker payudara digunakan penginduksi

$7,12-$

dimethylbenz(a)anthracene

(Sigma Chem.).

(DMBA)

\section{Subyek Uji}

Hewan uji yang digunakan adalah tikus putih betina galur Sprague dawley (SD), umur 30-40 hari, berat badan berkisar 60200 gram. Sampel diperoleh dari Laboratorium Hewan Universitas Airlangga

\section{Induksi karsinogenesis dengan DMBA dan perlakuan dengan ekstrak sambiloto (Andrographis paniculata Nees)}

Dua puluh lima ekor tikus putih betina usia 30-40 hari dibagi menjadi lima kelompok secara random. Kelompok I sebagai kontrol (diberi makanan kontrol, yaitu pellet AD produksi PT COMFED Surabaya, kelompok II (perlakuan DMBA saja), Kelompok III, IV dan V (perlakuan setelah tahap karsinogenesis dengan pemberian ekstrak sambiloto). Inisiasi DMBA diberikan 2 kali seminggu dengan dosis 20 $\mathrm{mg} / \mathrm{kg}$ BB selama 5 minggu. Kelompok III, IV dan $\mathrm{V}$ diberi ekstrak sambiloto dengan dosis masing-masing 100, 300 dan 1000 $\mathrm{mg} / \mathrm{kg}$ BB selama enam minggu. Tikus ditimbang setiap minggunya dan mulai minggu ke-1 setelah pemberian DMBA dilakukan palpasi setiap minggu untuk mengetahui perkembangan tumor sampai minggu ke-8.

\section{Pemeriksaan Hispatologi dan Uji Imunohistokimia}

Setelah pengamatan palpasi selesai, hewan dikorbankan 48 jam setelah pemberian sampel uji kemudian jaringan tumor diambil dan dibersihkan pembuluh darah serta lemak sekitranya untuk diukur volume tumornya. Jaringan kemudian dipreparasi dengan melakukan fiksasi menggunakan neutral buffered formalin dan dibuat sediaan. Sediaan terdiri dari dua yaitu sediaan dengan pewarnaan Hematoxyline Eosin terhadap organ mammae, untuk mengetahui keadaan sitologinya serta tingkat keparahan tumor atau kanker yang terjadi dan sediaan untuk imunohistokimia yang mana untuk uji imunohistokimia potongan ditempatkan dalam beberapa object glass yang telah diberi polylisine untuk selanjutnya dilakukan pemrosesan untuk pemeriksaan ekspresi enzim telomerase dengan pengecatan secara imunohistokimia. Slide yang telah diwarnai, diamati dengan mikroskop cahaya dengan pembesaran 400 kali.

\section{Analisis data}

Insidensi tumor dihitung dari jumlah tikus yang terkena tumor pada tiap kelompok dengan mengukur volume dan berat tumor serta pada uji imunohistokimia penghitungan sel yang positif terwarnai dilakukan dengan metode skoring Allred Score. 
Efek ekstrak sambiloto (Andrographis paniculata nees.) Pada ekspresi telomerase dari kanker payudara tikus yang diinduksi DMBA

HASIL DAN PEMBAHASAN

Pengaruh pemberian ekstrak sambiloto terhadap berat badan

Perkembangan berat badan tikus masingmasing kelompok dapat dilihat dalam gambar 1 dan 2 yang merupakan hasil penimbangan berat badan setiap minggu.

Dari gambar 1 tersebut dapat dilihat bahwa pemberian DMBA tidak mempengaruhi pertumbuhan normal tikus yang hanya diberi corn oil dan pada gambar 2 dari pemberian ekstrak sambiloto setelah induksi DMBA tidak mempengaruhi pertumbuhan normal tikus. Hal ini dikarenakan masing-masing kelompok suatu saat terjadi kemungkinan dikarenakan jumlah makanan dan minuman yang dikonsumsi sebelum dilakukan penimbangan, kondisi lingkungan dan stress akibat perlakuan.

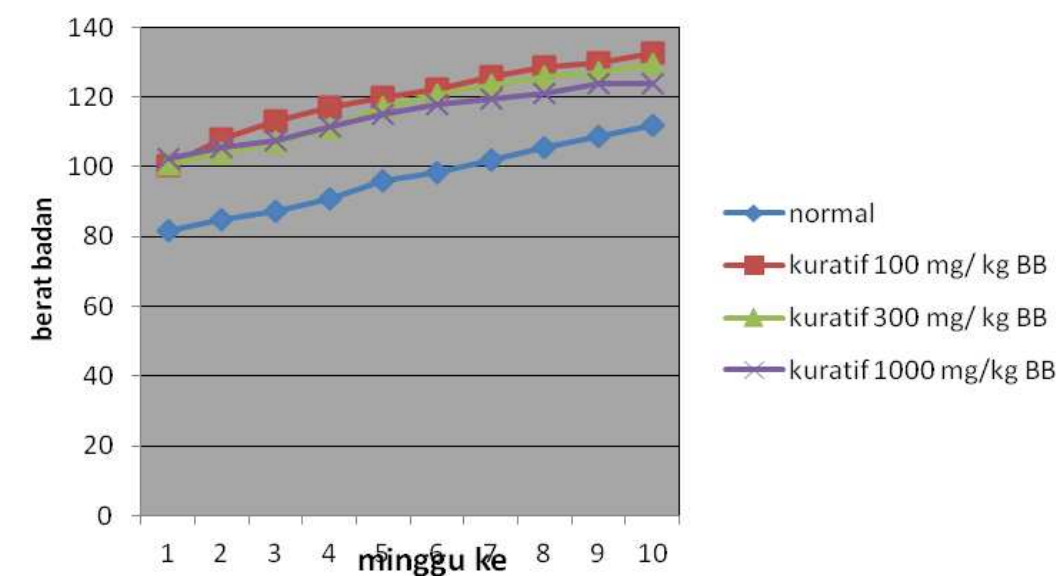

Gambar 1. Perkembangan berat badan tikus SD kelompok normal dan pemberian sampel uji masingmasing dosis (setelah induksi DMBA)

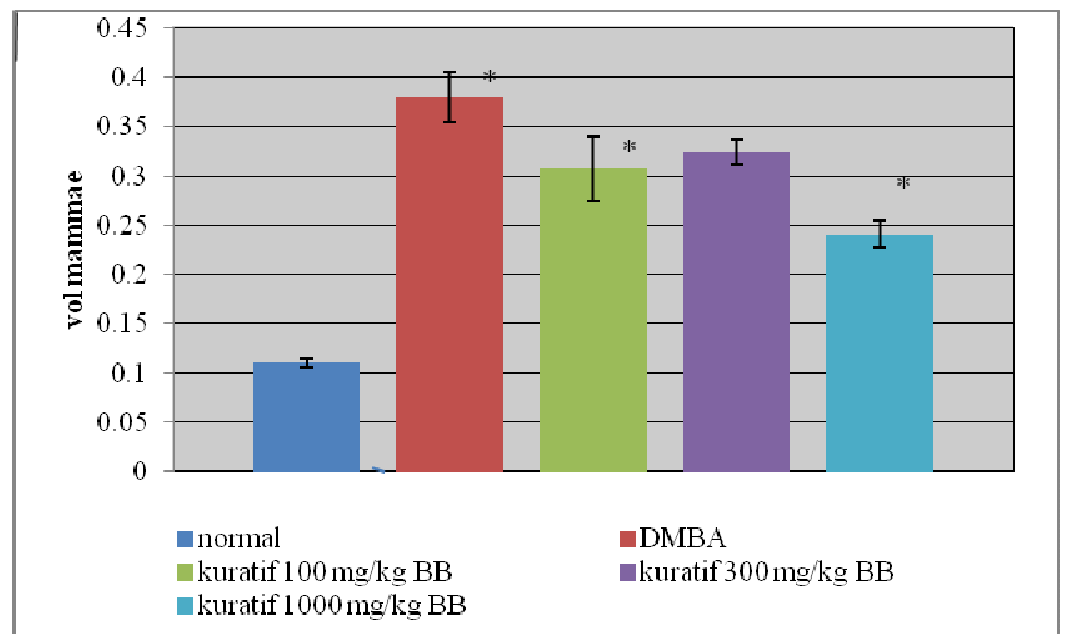

Gambar 2. Volume kelenjar payudara tikus SD pada kelompok normal, yang diinduksi DMBA dan pemberian ekstrak sambiloto

Ket : *) berbeda secara signifikan kelompok normal, DMBA vs $100 \mathrm{mg} / \mathrm{kg}$

BB dan $1000 \mathrm{mg} / \mathrm{kg}$ BB dengan $\left.F_{(4,17)}=92,777 ; p<0,05\right)$ melalui uji anova satu arah 
Efek ekstrak sambiloto (Andrographis paniculata nees.) Pada ekspresi telomerase dari kanker payudara tikus yang diinduksi DMBA

\section{Pengaruh pemberian ekstrak sambiloto terhadap volume kelenjar payudara tikus}

Hasil penelitian efek antikanker ekstrak sambiloto (Andrographis paniculata Nees) pada kanker payudara tikus. Prevalensi kanker dapat dilihat dari munculnya nodul pada masing-masing kelenjar payudara dan terutama setelah dilakukan pengorbanan terhadap hewan yaitu dengan mengukur volume kelenjar payudara model kanker yang berbeda dengan kelompok normal dan kelompok uji. Rata-rata volume kelenjar payudara serta prevalensi kanker payudara pada tikus akibat induksi DMBA dapat dilihat gambar 3 .

Dari gambar 3 dapat dijelaskan bahwa terdapat perbedaan volume kelenjar payudara antara kelompok normal dan yang di induksi DMBA. Dimana berdasarkan hasil palpasi dan pengukuran volume kelenjar payudara, didapatkan prevalensi kanker payudara $75 \%$. Berdasarkan analisa statistik melalui uji ANOVA satu arah pada kelompok normal, model kanker (DMBA) dan sampel uji berbagai dosis menunjukkan perbedaan volume secara bermakna dengan $\mathrm{p}<0,001$.

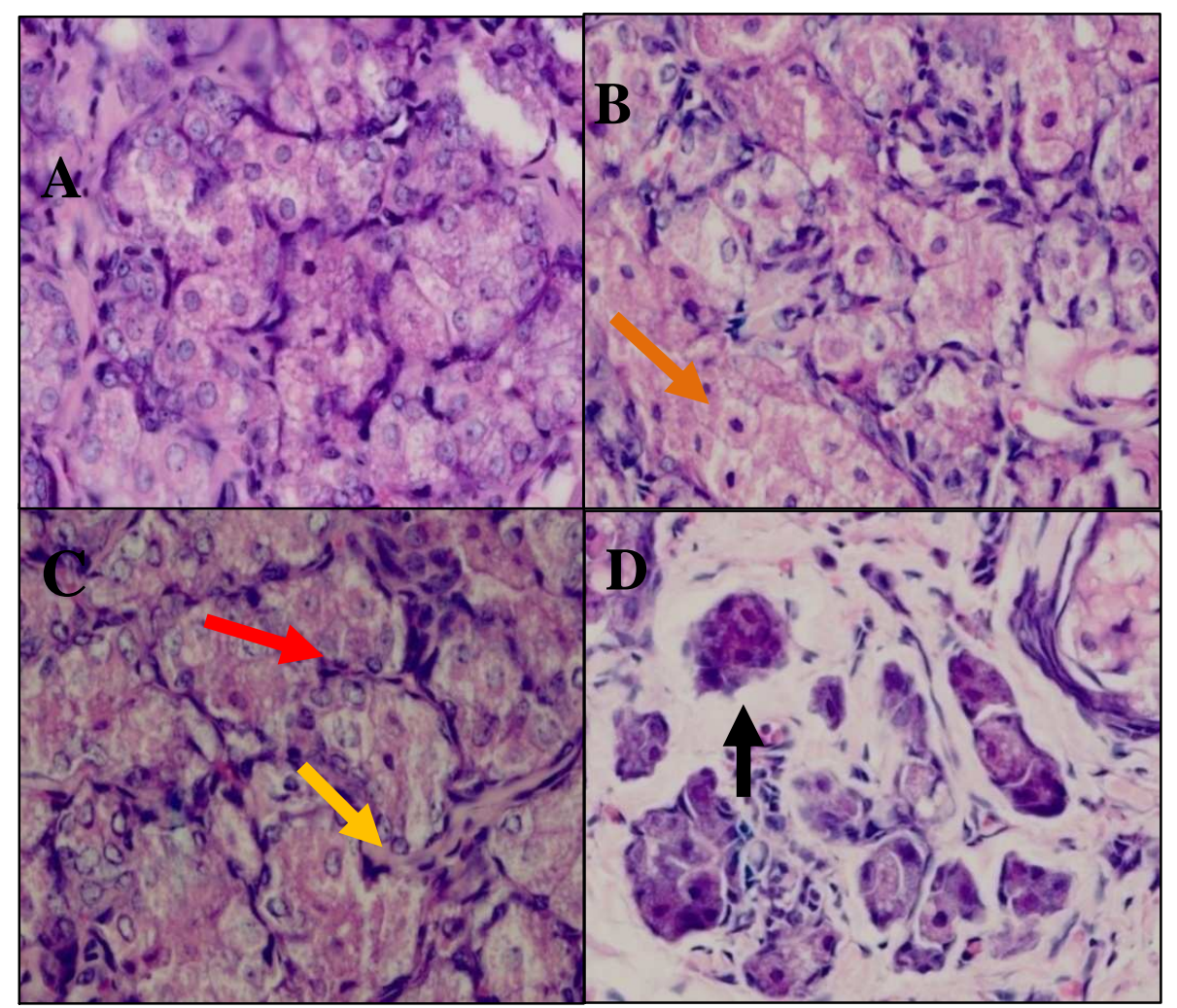

Gambar 3. Gambaran Histopatologi Kelenjar Payudara tikus SD Menggunakan Pewarnaan HematoxylinEosin yang diberi Oleum Maydis (A) Ekstrak Sambiloto $100 \mathrm{mg} / \mathrm{kg}$ BB (B). Ekstrak Sambiloto $300 \mathrm{mg} / \mathrm{kg} \mathrm{BB} \mathrm{(C)} \mathrm{Ekstrak} \mathrm{Sambiloto} 1000 \mathrm{mg} / \mathrm{kg}$ BB (D) (pembesaran $400 \mathrm{X}$ )

Keterangan: Fragmentasi inti akibat apoptosis $(\longrightarrow)$, jaringan ikat $(\longrightarrow)$, nekrosis $(\longrightarrow$ ), jaringan lemak ( 
Efek ekstrak sambiloto (Andrographis paniculata nees.) Pada ekspresi telomerase dari kanker payudara tikus yang diinduksi DMBA

\section{Pengaruh pemberian ekstrak terhadap perubahan morfologi, apoptosis dan proliferasi pada sel-sel epitel kelenjar payudara tikus.}

Dalam mengetahui perubahan morfologi, apoptosis dan proliferasi pada sel-sel epitel kelenjar payudara tikus, maka dilakukan pembedahan tikus dan diambil kelenjar payudara dari masing-masing kelompok untuk dipreparasi secara histokimia dengan pewarnaan Hematoxylin-Eosin. Perbedaan gambaran histopatologi kelenjar payudara antara normal dengan hewan yang mendapatkan induksi DMBA kemudian dengan ekstrak sambiloto masing-masing dosis dapat dilihat pada gambar 4 .

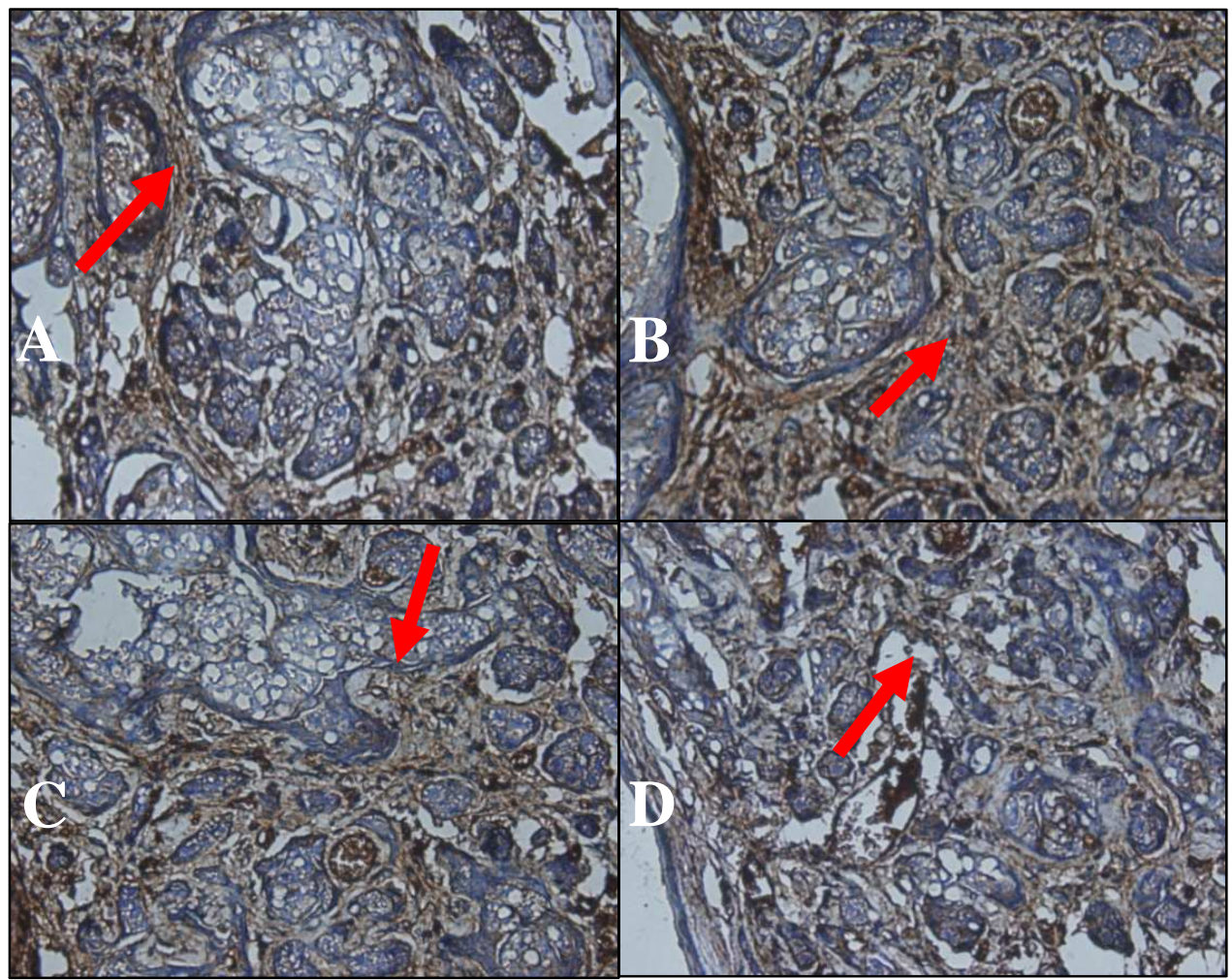

Gambar 4. Pewarnaan Imunohistokimia Menggunakan Antibodi Telomerase pada Irisan Melintang Kelenjar Payudara Tikus SD,dengan Perbesaran 400x: yang diberi DMBA (A), Ekstrak Sambiloto $100 \mathrm{mg} / \mathrm{kg}$ BB (B), Ekstrak Sambiloto $300 \mathrm{mg} / \mathrm{kg} \mathrm{BB} \mathrm{(C),} \mathrm{Ekstrak} \mathrm{Sambiloto} 1000$ $m g / k g B B(D)$

Keterangan : ekspresi enzim telomerase (>) 
Efek ekstrak sambiloto (Andrographis paniculata nees.) Pada ekspresi telomerase dari kanker payudara tikus yang diinduksi DMBA

Pada gambar 4, hewan yang diberi treatment sambiloto $100 \mathrm{mg} / \mathrm{kg}$ BB (B), sel tumor tampak berkurang dibanding dengan hewan yang dipapar DMBA (A) dan juga tampak sitoplasma yang lebih merah karena adanya fragmentasi inti akibat apoptosis, bentukan kelenjar mulai jelas, sel lemak mulai tampak dan diantara kelompok sel timbul jaringan ikat sehingga sel tumor yang terlokalisir

Pada irisan melintang kelenjar payudara hewan yang di treatment dengan sambiloto $300 \mathrm{mg} / \mathrm{kg}$ BB (C), disini juga tampak sitoplasma yang lebih merah akibat fragmentasi inti akibat apoptosis, jaringan ikat mulai terlokalisir lebih jelas dan sel tumor berkurang serta banyak sel tumor mati dan diisi oleh jaringan fibroblast. Disini juga tampak nekrosis yang ditandai dengan warna kemerahan berupa sel kosong.

Pada irisan kelenjar payudara hewan yang di treatment dengan sambiloto $1000 \mathrm{mg} / \mathrm{kg}$ BB (D), tampak sel kelenjar mulai tersusun homogen dan berkurangnya bentukan inti pleumorfik dan juga tampak nekrosis yang ditandai dengan warna kemerahan dan tidak ada sel.

\section{Pengaruh ekstrak sambiloto terhadap enzim telomerase dengan uji imunohistokimia}

Telomerase merupakan suatu enzim yang mengkatalisis pembentukan telomer yang berfungsi melindungi kromosom. Adanya hambatan pada enzim telomerase maka akan menyebabkan hambatan pembentukan telomerase sehingga kromosom tidak ada yang melindungi yang menyebabkan terjadinya proses fragmentasi pada kromosom sehingga sel akan mengalami apoptosis. Untuk melihat ekspresi protein telomerase pada sel-sel epitel kelenjar payudara tikus SD, jaringan yang telah dipreparasi dan hasil potongan ditempatkan dalam beberapa object glass yang telah diberi polylisine untuk selanjutnya dilakukan pemrosesan aktivitas telomerase dengan pengecatan secara imunohistokimia. Gambar 4 merupakan hasil analisis berdasarkan penelitian yang telah dilakukan.

Pada hewan yang diberi treatment dengan sambiloto dosis $100 \mathrm{mg} / \mathrm{kg} \mathrm{BB}$ yang terlihat pada gambar 4 (B), menunjukkan adanya ekspresi telomerase (ditunjukkan tanda yang masih terlihat banyak pada inti sel namun bila dibandingkan dengan kelompok normal gambar (A), jumlah sel yang terekspresikan lebih sedikit. Sedangkan untuk hewan yang diberi treatment dengan sambiloto dosis $300 \mathrm{mg} /$ $\mathrm{kg}$ BB (C) dan $1000 \mathrm{mg} / \mathrm{kg}$ BB (D) nampak adanya penurunan ekspresi telomerase di inti sel. Ini diikuti juga oleh hasil skoring pada Tabel 1. Hal ini membuktikan bahwa ekstrak sambiloto mampu menurunkan aktivitas enzim telomerase pada sel kelenjar kanker payudara.

Tabel 1. Data Skoring Pengamatan Berdasarkan Metode Allred Score pada Irisan Melintang Kelenjar Payudara Tikus SD yang diberi Ekstrak Sambiloto dengan Pewarnaan Imunohistokimia Menggunakan Antibodi Telomerase

\begin{tabular}{lcc}
\hline & Kelompok & Skoring \\
\hline DMBA & 4 \\
Dosis $100 \mathrm{mg} / \mathrm{kg} \mathrm{BB}$ & 4 \\
Dosis $300 \mathrm{mg} / \mathrm{kg} \mathrm{BB}$ & 3 \\
Dosis $1000 \mathrm{mg} / \mathrm{kg} \mathrm{BB}$ & 3 \\
\hline
\end{tabular}


Efek ekstrak sambiloto (Andrographis paniculata nees.) Pada ekspresi telomerase dari kanker payudara tikus yang diinduksi DMBA

\section{PEMBAHASAN}

Telah banyak dilakukan penelitian mengenai efek antikanker pada sambiloto khususnya kanker payudara, dan telah didapatkan hasil bahwa senyawa yang terkandung di dalam ekstrak sambiloto yaitu andrografolida. Pemberian ekstrak sambiloto pada percobaan ini dapat mengurangi tingkat progresifitas tumor setelah inisiasi DMBA. Adanya hambatan ini dimungkinkan karena daya hambatan perkembangan tumor tahap awal melalui modulasi proliferasi sel. Andrografolida yang terkandung dalam ekstrak mampu menghambat pertumbuhan nodul tumor, meningkatkan apoptosis dan menginhibisi proliferasi sel. Hasil ini juga sesuai dengan yang ditunjukkan pada sifat sitotoksiknya pada kanker payudara. Andrografolida dalam ekstrak sambiloto juga dapat menghambat efek DNA topoisomerase II sehingga proses replikasi, transkripsi dan proliferasi sel mengalami penurunan (Sukardiman, 2000), menginduksi inhibitor sel, p27 dan cyclin dependent kinase inhibitor (cdki) (Satyarayana et al, 2004) serta meningkatkan induksi apoptosis melalui reseptor kematian dari tumor necrosis factor-related apoptosis inducing ligand) (Zhou, 2008). Adanya aktivasi p53 oleh Andrografolida melalui stabilisasi p53 yang selanjutnya akan mempengaruhi proses siklus sel sehingga sel tidak akan mengalami pembelahan dan sel akan mati karena terjadi kondensasi kromosom yang menyebabkan terjadinya apoptosis (Andrew et al., 2002; Yalon et al., 2004) sehingga berdasarkan dari penelitian tersebut maka diduga ekstrak sambiloto mempunyai aktivitas antimitosis dan propoptosis pada sel tumor. Obat yang mempunyai efek antimitosis diduga juga mempunyai efek antitelomerase yang dapat menghambat pembelahan dan perkembangan sel yang sangat cepat seperti sel kanker dan berakibat terjadi kematian sel (apoptosis) (Anonim, 2004).

Telomerase adalah suatu ribonucleoprotein yang tersusun berulang terdiri dari C4-A2 dan G4-72 berfungsi mensintesis telomer yang berperan penting dalam menjaga stabilitas kromosom dan telomer akan mengalami pemendekan pada waktu sel melakukan pembelahan diri. Telomerase akan tetap aktif pada sel benih dan tidak aktif pada sel somatik namun telomerase terinduksi kembali pada sel normal yang mengalami trasnformasi menjadi sel kanker (Lantuejoul et al., 2004). Adanya penurunan ekspresi telomerase pada kanker payudara yang sebanding dengan peningkatan dosis ekstrak sambiloto membuktikan bahwa ekstrak sambiloto mempunyai hambatan pada enzim telomerase melalui aktivasi protein p53 yang pada akhirnya menyebabkan sel epitel kanker payudara tersebut tidak mampu untuk terus membelah karena siklus sel tidak dapat berjalan akibat adanya hambatan pada pembentukan kompleks cyclin-CDK oleh protein p53 yang diperantarai oleh p21 akibatnya proliferasi sel epitel kanker payudara mengalami hambatan.

\section{KESIMPULAN}

Ekstrak sambiloto (Andrographis paniculata Nees) dapat menurunkan ekspresi enzim telomerase sel-sel kelenjar payudara yang diinduksi menjadi kanker payudara dengan 7,12-dimethlbenz(a) anthracene (DMBA) setelah diterapi ekstrak sambiloto (Andrographis paniculata Nees) sehingga berpotensi sebagai senyawa antikanker payudara. 
Efek ekstrak sambiloto (Andrographis paniculata nees.) Pada ekspresi telomerase dari kanker payudara tikus yang diinduksi DMBA

\section{UCAPAN TERIMA KASIH}

Terima kasih diucapkan kepada UP Fakultas Farmasi Universitas Mulawarman yang telah membiayai penelitian ini dan Universitas Airlangga atas penyediaan fasilitas dalam penelitian ini.

\section{DAFTAR PUSTAKA}

1. American Cancer Society, Inc. 2008, What You Can Do About Breast Cancer, Available from : http://www.cancer.org/docroot/CRI/content/CR I_2 4 1X What is breast cancer 5. asp, diakses 19 Juli 2009.

2. Surya. 15 Maret, 2004, Terapi Telomerase Atasi Kanker Hati; Surabaya.

3. Ganiswara, Sulistia, G.; dkk. 1995. Farmakologi dan Terapi edisi 4. Bagian Farmakologi, Fakultas Kedokteran-Universitas Indonesia; Jakarta. Hal. 686-701.

4. King, R.J.B. 2000, Cancer Biology, $2^{\text {nd }}$ ed. Harlow-England-London-New York: Pearson Education, pp.263-64

5. Kumar, R.A.; Sridevi, K.; \& Kumar, N.V. 2004, Anticancer and Immunostimulatory Compounds from Andrographis Paniculata. Journal of Ethnopharmacology 92(2-3):291-95

6. Kusumowardojo, P. T. 2004, Beberapa Aspek Sitologi \& Histologi Kanker Payudara, Indonesian Issue on Breast Cancer I; Surabaya, 1-17.

7. Lantuejoul.; Soria, S.J.C.; dkk. 2004. Differential Expression of Telomerase Reverse
Transcriptase (hTERT) in Lung Tumors, $J$. Cancer, Mar 22 : 90 (6) : 1222-9

8. Meiyanto, E.; Tasminatun, S.; Susilowati, S.; Murwanti, R.; \& Sugiyanto. 2007, Penghambatan Karsinogenesis Kanker Payudara Tikus Terinduksi DMBA pada Fase Post Inisiasi oleh Ekstrak Etanolik daun Gynura procumbens (Lour), Merr. Majalah Farmasi Indonesia. 18(4), 169-175

9. Satyanarayana, C.; Dhanavanthri, S.D.; Rajagopalan, R.; Nanduri, S.; \& Sriram, R. 2004, DCFR 3188 A Novel Semi Synthetic Analog of Andrographolide: Cellular Response to Mcf-7 Breast Cancer Cells. BMC Cancer 4(26): $1-8$

10. Sukardiman; Hadi, P.; Sofia, M.; \& Sismindari. 2000, Penapisan Senyawa Antikanker dari Tanaman Obat Indonesia dengan Molekul Target Enzim DNA Topoisomerase. Laporan Akhir Penelitian Domestic Collaborative Research Grant

11. Sukardiman. 2007, Mekanisme Induksi Apoptosis Pinaostrobin dari Kaemferia pandurata Roxb dan Andrografolida dari Andrographis paniculata Nees terhadap Sel Kanker Manusia Secara In Vitro dan Implikasinya Pada Penggunaan Secara In Vivo. Disertasi, Universitas Airlangga; Surabaya.

12. Yalon, M.; Gal, S.; Segev, Y.; \& Skorecki, K.L. 2004. Sister Chromatid separation at Human Telomeric Region. Journal Cell Sci

13. Zhou, J.; Lu, G.; Ong, C.; \& Shen, H. 2008, Andrographolide Sensitizes Cancer Cells to TRAIL-Induced Apoptosis via p53-mediated Death Receptor 4 Up-regulation. Molecular cancer Therapeutics 7:2170-180 